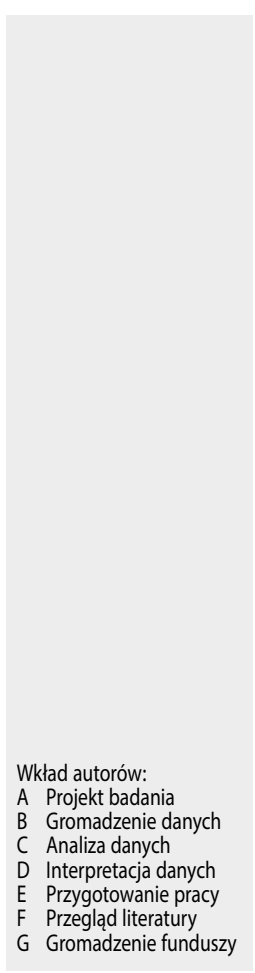

\title{
Karty Oceny Rozwoju Psychoruchowego (KORP) - opis narzędzia i prezentacja jego wykorzystania na przykładzie trzech studiów przypadku dzieci z zaburzeniami słuchu
}

\section{Psychomotor Development Evaluation Cards - description of the tool and presentation of its use on the example of three case studies of children with hearing impairments}

\author{
Małgorzata Ganc ${ }^{1 A B C D E F}$, Joanna Kobosko ${ }^{2 C D E F}$, W. Wiktor Jędrzejczak ${ }^{1 D E}$, \\ Anna Skoczylas ${ }^{2 C D E}$, Anna Geremek-Samsonowicz ${ }^{2 C D}$ \\ ${ }^{1}$ Instytut Fizjologii i Patologii Słuchu, Światowe Centrum Słuchu, Zakład Audiologii \\ Eksperymentalnej, Warszawa/Kajetany \\ ${ }^{2}$ Instytut Fizjologii i Patologii Słuchu, Światowe Centrum Słuchu, Klinika Rehabilitacji, \\ Warszawa/Kajetany
}

\begin{abstract}
Streszczenie
Wstęp: Prawidłowo funkcjonujące zmysły, w tym słuch, umożliwiają prawidłowy rozwój psychoruchowy dziecka. U dzieci z różnego rodzaju uszkodzeniami słuchu obserwuje się często opóźniony bądź nieharmonijny rozwój psychoruchowy. Karty Oceny Rozwoju Psychoruchowego (KORP) umożliwiają badanie wielu sfer rozwoju, a tym samym szybkie wykrycie nieprawidłowości rozwojowych. Za pomocą KORP można badać zarówno sferę motoryczną, poznawczą, w tym językową, jak również społeczno-emocjonalną oraz funkcje behawioralne, jak i poziom wiedzy i umiejętności uczenia się.

Cel: Celem pracy jest przedstawienie trzech różnych profili rozwoju psychoruchowego dzieci z zaburzeniami słuchu, otrzymanych za pomocą KORP: dziecka prelingwalnie głuchego, dziecka z jednostronną głuchotą oraz dziecka z centralnymi zaburzeniami przetwarzania słuchowego.

Material i metoda: W pracy przedstawiono wyniki trojga dzieci z zaburzeniami słuchu uzyskane w badaniu poziomu rozwoju psychoruchowego za pomocą KORP.

Wyniki: U dziewczynki M.L., lat 4, korzystającej z CI, badanie wykonane po 2 latach od aktywacji urządzenia wskazuje na niski poziom funkcjonowania dziecka w zakresie umiejętności językowych i uczenia się (próby związane ze słyszeniem). Dziewczynka R.P., lat 8 , z centralnymi zaburzeniami słuchu, wykazuje niski poziom funkcjonowania w 6 z 7 badanych sfer. Chłopiec P.A., lat 4, z jednostronną głuchotą, badany po 2 latach korzystania z CI, wykazuje prawidłowe funkcjonowanie psychoruchowe we wszystkich badanych sferach w odniesieniu do swojego wieku biologicznego.

Wnioski: KORP może być używany jako narzędzie umożliwiające przeprowadzenie wstępnej diagnozy rozwoju psychoruchowego dzieci z zaburzeniami słuchu i mowy. Uzyskane w tym badaniu wyniki mogą ułatwiać planowanie wielospecjalistycznej pomocy dzieciom z zaburzonym rozwojem psychoruchowym. Wyniki mogą wskazywać, które obszary funkcjonowania dziecka powinny zostać poddane głębszej diagnozie specjalistycznej, a po potwierdzeniu nieprawidłowości rozwojowych - jakie leczenie i rehabilitacja zaburzonych sfer rozwoju będą odpowiednie. KORP można wykorzystywać także w celu ewaluacji zastosowanych form wsparcia specjalistyczno-rehabilitacyjnego.

Słowa kluczowe: rozwój psychoruchowy • Karty Oceny Rozwoju Psychoruchowego • KORP • głuchota prelingwalna • głuchota jednostronna $\bullet$ centralne zaburzenia przetwarzania słuchowego $\bullet$ implant ślimakowy
\end{abstract}

Adres autora: Małgorzata Ganc, Zakład Audiologii Eksperymentalnej, Światowe Centrum Słuchu, Instytut Fizjologii i Patologii Słuchu, Kajetany, ul. Mokra 17, 05-830 Nadarzyn, m.ganc@ifps.org.pl 


\section{Abstract}

Introduction: Well-functioning senses, including hearing, enable the child's normal psychomotor development. In children with various types of hearing loss, delayed or non-harmonious psychomotor development is often observed. The Psychomotor Development Evaluation Cards (KORP) allow to study many developmental spheres, and thus allow also the rapid detection of developmental abnormalities. Using KORP, one can examine both the motor, cognitive (including linguistic), as well as socio-emotional, and behavioral functions, the level of knowledge and learning skills.

Aim: The aim of the study was to present by means of KORP three different profiles of psychomotor development of children with hearing impairments: a prelingually deaf child, a child with unilateral deafness and a child with central auditory processing disorders. Material and Method: The study presents the results of three children with hearing disorders obtained by the evaluation of the level of psychomotor development using KORP.

Results: In a girl M.L., aged 4, using CI, the test performed 2 years after the device activation indicates a low level of child's functioning in terms of language skills and learning (hearing-related tests). A girl R.P., aged 8, with central auditory processing disorders, shows a low level of functioning in 6 out of 7 spheres of functioning. The boy P.A., aged 4, with unilateral deafness, examined after 2 years of using the CI, shows normal psychomotor functioning in all studied areas in relation to his biological age.

Conclusions: KORP can be used as a tool enabling initial diagnosis of psychomotor development of children with hearing and speech disorders. The results obtained in this study may facilitate the planning of multi-specialist assistance for children with impaired psychomotor development. The results may indicate which areas of the child's functioning should be subjected to a deeper specialist diagnosis, and after confirmation, which treatment and rehabilitation should be applied. KORP can also be used to evaluate the applied forms of specialist and rehabilitation support.

Key words: psychomotor development • Psychomotor Development Evaluation Cards $\bullet$ KORP • prelingual deafness • unilateral deafness $\bullet$ central auditory processing disorder $\bullet$ cochlear implant

Wykaz skrótów

\begin{tabular}{|c|c|c|}
\hline Skrót & Rozwinięcie skrótu w języku angielskim & Znaczenie skrótu w języku polskim \\
\hline ABR & auditory brainstem response & słuchowe potencjały wywołane pnia mózgu \\
\hline ADHD & attention-deficit hyperactivity disorder & zespół nadpobudliwości psychoruchowej z deficytem uwagi \\
\hline APD & auditory processing disorder & zaburzenia przetwarzania słuchowego \\
\hline ATOS & - & asymetryczny toniczny odruch szyjny \\
\hline AVT & auditory-verbal therapy & terapia audytywno-werbalna \\
\hline $\mathrm{Cl}$ & cochlear implant & implant ślimakowy \\
\hline DDT & dichotic digit test & rozdzielnouszny test cyfrowy \\
\hline DPT & duration pattern test & test wzorców czasu trwania \\
\hline DSR & - & Dziecięca Skala Rozwojowa \\
\hline FPT & frequency pattern test & test wzorców częstotliwości \\
\hline $\mathrm{HL}$ & hearing level & poziom słyszenia \\
\hline KORP & Psychomotor Development Evaluation Cards & Karty Oceny Rozwoju Psychoruchowego \\
\hline SSD & single-sided deafness & jednostronna głuchota \\
\hline SPS & - & stymulacja percepcji słuchowej \\
\hline STOS & - & symetryczny toniczny odruch szyjny \\
\hline TOB & - & toniczny odruch błędnikowy \\
\hline UL & - & ucho lewe \\
\hline UP & - & ucho prawe \\
\hline
\end{tabular}

\section{Wstęp}

Rozwój psychoruchowy dziecka to ciąg zmian progresywnych, w których rozwój motoryczny jest ściśle związany ze sferą poznawczą i emocjonalno-motywacyjną [1]. Nieprawidłowo funkcjonujące zmysły, w tym szczególnie słuch, mogą zakłócać prawidłowy rozwój psychoruchowy jednostki. Zaburzenia percepcji słuchowej powodują, że dziecko ma duże trudności z rozwijaniem różnych kompetencji poznawczych, nie tylko językowych i komunikacyjnych [2].

W zależności od momentu pojawienia się niedosłuchu, jego rodzaju i głębokości, a także od tego, czy ubytek słuchu 
występuje jednostronnie czy obuusznie oraz czy ma charakter zmysłowo-nerwowy czy centralny [3], stosowane są różne formy leczenia, w tym implantacja ślimakowa [4], oraz terapie, np. terapia audytywno-werbalna (AVT) [5], czy treningi, np. treningi słuchowe [6], EEG Biofeedback [7-8], metoda Tomatisa [9], SPS metodą Skarżyńskiego [10], logorytmika [11], ogólnorozwojowe zajęcia z psychomotoryki [12-13], i/lub programy wspierające rozwój emocjonalny i społeczny [14-15]. Dzieci z różnymi zaburzeniami słuchu i ich rodzice (rodziny) otrzymują pomoc psychologiczną i pedagogiczną [16-18].

U dzieci z głębokim ubytkiem słuchu, które są pozbawione możliwości odbioru informacji w postaci dźwiękowej, rozwój psychoruchowy przebiega zazwyczaj nieprawidłowo w wybranych sferach. Obserwowane są trudności w zakresie orientacji w schemacie ciała i przestrzeni, zaburzenia w sferze emocjonalnej i behawioralnej, a nabywanie mowy i języka (fonicznego), jak i rozwój procesów poznawczych u dzieci niesłyszących przebiegają w inny sposób niż słyszących [19-20]. U dzieci ze znacznym i głębokim ubytkiem słuchu najczęściej stosowana jest implantacja ślimakowa. Od percepcji słuchowej uzależnione jest między innymi opanowywanie przez dziecko umiejętności czytania i pisania, opanowanie słownictwa czy tworzenie nowych pojęć [21]. Wyniki badań prowadzonych wśród dzieci głuchych w wieku szkolnym, będących użytkownikami implantów ślimakowych, wskazują na niższy poziom ich funkcjonowania zarówno w zakresie umiejętności językowych, poznawczych, jak i osiąganych wyników szkolnych [22-23]. Badania obejmujące gimnazjalistów z głuchotą prelingwalną i częściową, użytkowników CI, pokazały, że wiek dzieci w momencie implantacji różnicuje poziom prezentowanej wiedzy na zakończenie nauki w szkole podstawowej. Dzieci, które zaczęły korzystać z CI przed ukończeniem 2,5 lat, uzyskały lepsze wyniki ogólne w teście na zakończenie edukacji w szkole podstawowej oraz $\mathrm{w}$ teście czytania niż dzieci zaimplantowane $\mathrm{w}$ wieku pomiędzy 4,5 a 6,7 lat [24].

U osób z głębokimi jednostronnymi uszkodzeniami słuchu (SSD) obserwuje się trudności w lokalizacji źródła dźwię$\mathrm{ku}$, nieprawidłowy przebieg lateralizacji słuchowej, a często także - trudności szkolne i wychowawcze [25]. Pacjenci skarżą się na słabe rozumienie mowy w hałasie, efekt cienia głowy oraz na obniżoną jakość życia [26].

Inną grupę dzieci z zaburzeniami słuchu stanowią dzieci z centralnymi zaburzeniami przetwarzania słuchowego (APD) [3, 27-29]. U tych dzieci, pomimo prawidłowej czułości słuchu, nieprawidłowo przebiegają procesy przetwarzania informacji akustycznej na wyższych piętrach drogi słuchowej. Centralne zaburzenia słuchu często współwystępują z nieprawidłowym rozwojem mowy, ADHD, dysleksją, zaburzeniami emocjonalnymi i społecznymi, a także trudnościami szkolnymi [28,30-31].

Ze względu na to, że zaburzenia słuchu często wiążą się z trudnościami w rozwoju psychoruchowym u dzieci, celowe wydaje się przeprowadzanie diagnozy poszczególnych sfer funkcjonowania psychomotorycznego dzieci z nieprawidłowym słuchem. Do oceny rozwoju psychoruchowego dzieci stosowane są różne narzędzia, jak np.: Skala Rozwoju Psychoruchowego Brunet-Lézine [32], Skala Inteligencji
Termana-Merrill [33], Dziecięca Skala Rozwojowa (DSR) [34] czy Międzynarodowa Wykonaniowa Skala Leitera [35]. Wymienione powyżej narzędzia zostały zastrzeżone do stosowania wyłącznie przez psychologów i tylko niektóre z nich mają normy dla dzieci głuchych [36]. Narzędziem polskim, które umożliwia dokonanie oceny dzieci w wieku od 1. miesiąca do ukończenia 9. roku życia przez każdego terapeutę niebędącego psychologiem, który przeszedł wymagane przeszkolenie w jego stosowaniu, są Karty Oceny Rozwoju Psychoruchowego (KORP) [37].

\section{Materiał i metoda}

\section{Osoby badane}

Troje dzieci z zaburzeniami słuchu i mowy:

- Dziewczynka M.L. (4 lata) - z głębokim obustronnym niedosłuchem, użytkowniczka CI, badana po 24 miesiącach od aktywacji CI.

- Dziewczynka P.R. (8 lat i 10 miesięcy) - ze zdiagnozowanymi centralnymi zaburzeniami przetwarzania słuchowego i opóźnionym rozwojem mowy, uczennica klasy 3.

- Chłopiec A.P. (4 lata i 1 miesiąc) - z jednostronną głuchotą prawego ucha, prawdopodobnie od urodzenia, użytkownik CI, badany po 24 miesiącach od aktywacji CI.

\section{Karty Oceny Rozwoju Psychoruchowego}

KORP jest polskim narzędziem wystandaryzowanym i znormalizowanym, opracowanym przez Elżbietę Bogacz i Annę Bogacz-Rybczak [37], które umożliwia kompleksową ocenę rozwoju dziecka od 1. miesiąca do końca 9. roku życia. Korzystać z niego może szeroka grupa specjalistów: pedagodzy, psycholodzy, logopedzi, fizjoterapeuci, pod warunkiem ukończenia szkolenia u autorek narzędzia i otrzymania certyfikatu potwierdzającego uzyskanie uprawnień do jego stosowania. Za pomocą kart KORP możliwe jest przeprowadzenie oceny rozwoju dziecka w takich sferach funkcjonowania, jak: sfera ruchowa, motoryka precyzyjna i lateralizacja, spostrzeganie wzrokowe i koordynacja wzrokowo-ruchowa, komunikowanie się i mowa, sfera emocjonalna i relacji społecznych, sfera funkcji behawioralnych oraz umiejętności przedszkolnych (dla dzieci w wieku od 3;0 do 5;11 lat) lub szkolnych (dla dzieci w wieku od 6;0 do 9;11 lat). Do oceny rozwoju dziecka opracowano 13 rodzajów kart dostosowanych do określonych przedziałów wiekowych. W pierwszym roku życia karty wypełniania się co kwartał, pomiędzy 1. a 2. rokiem życia - co pół roku (od 12. do 17. i od 18. do 23. miesiąca życia), a od 2. roku życia do końca 7. - w odstępach rocznych. Natomiast w przypadku dzieci w wieku od 8. do końca 9. roku życia wykorzystywana jest jedna karta. Opracowano także karty wywiadu dla rodziców zawierające szczegółowe pytania dotyczące okresu ciąży, porodu i dotychczasowego rozwoju dziecka.

KORP pozwala ocenić, czy rozwój psychoruchowy dziecka przebiega harmonijnie w odniesieniu do grupy wiekowej w obszarze ważnych sfer rozwoju, mających duże znaczenie dla jego funkcjonowania społecznego i osiągnięć edukacyjnych. W przypadku stwierdzenia nieprawidłowości, dysharmonii bądź opóźnień rozwojowych KORP stanowi 
podstawę do skierowania dziecka na dalsze badania i konsultacje specjalistyczne oraz ułatwia opracowanie optymalnego planu wielospecjalistycznej pomocy dzieciom o zaburzonym rozwoju psychoruchowym.

\section{Dokumentacja medyczna}

Wykorzystano informacje zawarte w książeczce zdrowia dzieci, jak również przeanalizowano informacje zawarte w kartach ambulatoryjnych i szpitalnych opisywanych pacjentów.

\section{Wywiady $\mathrm{z}$ rodzicami}

Umożliwiły uzyskanie dodatkowych informacji na temat rozwoju dzieci i sytuacji socjalno-zdrowotnej ich rodziców i rodzeństwa.

\section{Studium przypadku I}

Dziewczynka M.L. - w wieku 4 lat, z obustronnym głębokim niedosłuchem zmysłowo-nerwowym, korzysta $\mathrm{z}$ jednego CI w uchu prawym i aparatu słuchowego w UL (Oticon Safari 600), od września 2017 roku uczęszcza do przedszkola integracyjnego. Rodzina pełna, u ojca zdiagnozowano niedosłuch wysokoczęstotliwościowy, rodzeństwo i matka słyszący. Badanie kartami KORP przeprowadzono po 24 miesiącach od aktywacji CI.

Dane medyczne. Dziecko urodziło się w 40. tygodniu ciąży przez cesarskie cięcie, z masą urodzeniową 3850 g, stan po urodzeniu oceniono na 10 punktów w skali Apgar. Dziewczynka nie chorowała na zapalenie uszu, a rozwój motoryczny przebiegał prawidłowo. Wad wrodzonych i chorób przewlekłych nie wykryto. Wynik badania USG przezciemiączkowego był prawidłowy. Z powodu obniżonego napięcia mięśniowego była rehabilitowana w pierwszym roku życia. W przeprowadzonych badaniach molekularnych wykryto homozygotyczną mutację 35delG genu GJB2. Operację wszczepienia implantu ślimakowego

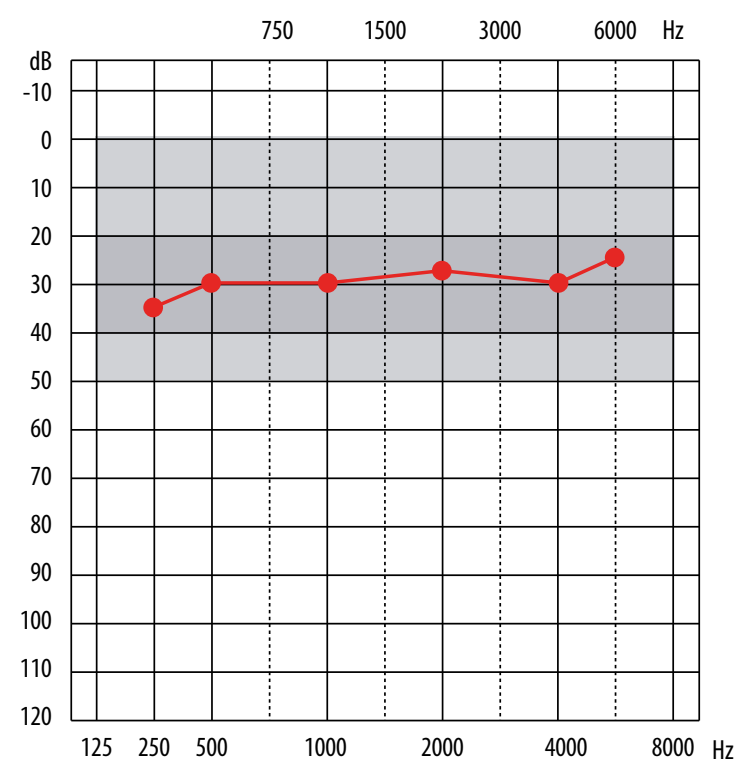

Rycina 1. Audiogram M.L. w polu swobodnym w Cl

Figure 1. Free field audiogram in $\mathrm{Cl}$ of the subject M.L. firmy MED-EL (Synchrony) do ucha prawego przeprowadzono w listopadzie 2016 roku, a aktywacja procesora mowy odbyła się po miesiącu, kiedy dziewczynka miała ukończone 2 lata.

Wyniki badań audiologicznych. Przesiewowe badania słuchu przeprowadzone na oddziale noworodkowym wykazały wynik nieprawidłowy. Niedosłuch został potwierdzony dwukrotnie badaniem ABR, w którym nie zarejestrowano fali V w zakresie do $100 \mathrm{~dB}$ zarówno dla bodźca tonalnego $1 \mathrm{kHz}$, jak i dla trzasku $(2-4 \mathrm{kHz})$. W wieku 6 miesięcy dziewczynka otrzymała aparaty słuchowe. Przed implantacją w badaniu impedancyjnym zarejestrowano tympanogramy typu A, a odruchów ipsilateralnych z mięśnia strzemiączkowego nie wywołano. Badanie audiometryczne po 2 latach od implantacji wykazało próg słyszenia w polu swobodnym w CI na poziomie ok. 25-40 dB HL w szerokim zakresie częstotliwości (UP CI/UL otwarte).

Rozwój mowy i języka. Po pół roku korzystania z aparatów słuchowych i intensywnej rehabilitacji rodzice zaczęli zauważać powtarzalne reakcje na bodźce akustyczne oraz pojawiły się pierwsze słowa. Zdecydowali się na kontynuowanie rehabilitacji $\mathrm{w}$ oparciu o aparaty słuchowe, do komunikacji włączane były także znaki języka migowego. Po pewnym czasie rodzice zauważyli, że dziewczynka nie robi już postępów w rozwoju słuchowym, wspomaga się „czytaniem z ruchu warg”, denerwuje się, gdy nie może komunikować się z otoczeniem, dlatego zdecydowali się na implantację. Przed otrzymaniem CI w słowniku czynnym dziewczynki znajdowały się wyrazy i wypowiedzenia: mama, tata, lala, pa, pa, daj, nie, nie ma, Michat, brawo. Reagowała na proste polecenia: daj, chodź, nie.

Po implantacji dziewczynka zaczęła systematycznie uczestniczyć w zajęciach logopedycznych po 3-4 godziny tygodniowo. Aktualnie potrafi budować proste zdania 3-4-wyrazowe, rozumie coraz lepiej komunikaty słowne i ma coraz większy zasób słownictwa. Jej mowa nadal jest nie w pełni rozumiana przez otoczenie.

Ocena aktualnego rozwoju psychoruchowego $\mathrm{z}$ wykorzystaniem KORP. Po 2 latach korzystania $z$ implantu ślimakowego u dziecka przeprowadzono badanie aktualnego poziomu rozwoju psychoruchowego kartami KORP (rycina 2).

Wyniki uzyskane w próbach testowych analizowano w odniesieniu do poszczególnych sfer funkcjonowania. Rozwój motoryczny zarówno w obszarze dużej motoryki, jak i motoryki precyzyjnej i lateralizacji w porównaniu do grupy normatywnej znajduje się na poziomie odpowiadającym wiekowi biologicznemu dziewczynki. Umiejętności spostrzegania wzrokowego i koordynacji wzrokowo-ruchowej oraz poziom rozwoju emocjonalno-społecznego i funkcji behawioralnych dziewczynka prezentuje na wysokim poziomie. Próby sprawdzające kompetencje z obszaru komunikacji i mowy oraz wiedzy i umiejętności uczenia się sprawiały dziewczynce trudności i w porównaniu $\mathrm{z}$ grupą normatywną te umiejętności są na niskim poziomie. Umiejętności komunikacyjne i mowę dziecko rozwinęło na poziomie dzieci w wieku od 24 do 36 miesięcy, a wiedza odpowiada poziomowi dzieci 3-letnich rozwijających się typowo. 
Rycina 2. Karta KORP dziewczynki M.L.

Figure 2. KORP profile for the subject M.L.

\begin{tabular}{|c|c|c|c|c|c|c|c|c|c|c|c|c|c|c|c|}
\hline \multicolumn{16}{|c|}{ Karty Oceny Rozwoju Psychoruchowego } \\
\hline \multirow[t]{2}{*}{ 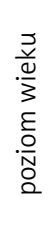 } & \multirow[t]{2}{*}{$\begin{array}{l}\varepsilon \\
\frac{\varepsilon}{N} \\
\stackrel{\circ}{\alpha}\end{array}$} & \multicolumn{2}{|c|}{$\begin{array}{l}\text { Rozwój } \\
\text { ruchowy }\end{array}$} & \multicolumn{2}{|c|}{$\begin{array}{c}\text { Rozwój } \\
\text { motoryki } \\
\text { precyzyjnej } \\
\text { i lateralizacji }\end{array}$} & \multicolumn{2}{|c|}{$\begin{array}{c}\text { Rozwój } \\
\text { spostrzegania } \\
\text { wzrokowego } \\
\text { i koordynacji } \\
\text { wzrokowo- } \\
\text { ruchowej }\end{array}$} & \multicolumn{2}{|c|}{$\begin{array}{c}\text { Rozwój } \\
\text { komunikowania } \\
\text { się i mowy }\end{array}$} & \multicolumn{2}{|c|}{$\begin{array}{l}\text { Rozwój } \\
\text { emocjonalno- } \\
\text { społeczny }\end{array}$} & \multicolumn{2}{|c|}{$\begin{array}{l}\text { Rozwój funkcji } \\
\text { behavioralnych }\end{array}$} & \multicolumn{2}{|c|}{$\begin{array}{l}\text { Wiedza } \\
\text { i umiejętności } \\
\text { uczenia się }\end{array}$} \\
\hline & & Prób) & Poziom & Próby & Poziom & Próby & Poziom & Próby & Poziom & Próby & Poziom & Próby & Poziom & Próby & Poziom \\
\hline \multirow{6}{*}{ 莡 } & \multirow{2}{*}{ W } & A1 & & B1 & & $\mathrm{C} 1$ & & D1 & & E1 & & F1 & & G1 & \\
\hline & & A2 & & B2 & & $\mathrm{C} 2$ & & D2 & & E2 & & F2 & & G2 & \\
\hline & \multirow{2}{*}{$P$} & A3 & & B3 & & C3 & & D3 & & E3 & & F3 & & G3 & \\
\hline & & A4 & & B4 & & $\mathrm{C} 4$ & & D4 & & E4 & & F4 & & G4 & \\
\hline & \multirow{2}{*}{$\mathrm{N}$} & A5 & & B5 & & $\mathrm{C} 5$ & & D5 & & E5 & & F5 & & G5 & \\
\hline & & A6 & & B6 & & $\mathrm{C} 6$ & & D6 & & E6 & & F6 & & G6 & \\
\hline \multirow{6}{*}{ 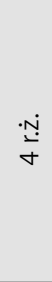 } & \multirow{2}{*}{ W } & A1 & & B1 & & C1 & & D1 & & E1 & & F1 & & G1 & \\
\hline & & $A 2$ & & B2 & & $\mathrm{C} 2$ & & D2 & & E2 & & F2 & & $\mathrm{G} 2$ & \\
\hline & \multirow{2}{*}{$\mathrm{P}$} & A3 & & B3 & & $\mathrm{C} 3$ & & D3 & & E3 & & F3 & & G3 & \\
\hline & & A4 & & B4 & & C4 & & D4 & & E4 & & F4 & & G4 & \\
\hline & \multirow{2}{*}{$\mathrm{N}$} & A5 & & B5 & & $\mathrm{C} 5$ & & D5 & & E5 & & F5 & & G5 & \\
\hline & & A6 & & B6 & & C6 & & D6 & & E6 & & F6 & & G6 & \\
\hline \multirow{6}{*}{$\stackrel{\text { N }}{m}$} & \multirow{2}{*}{ W } & A1 & & B1 & & $\mathrm{C} 1$ & & D1 & & E1 & & F1 & & G1 & \\
\hline & & A2 & & B2 & & $C 2$ & & D2 & & E2 & & F2 & & G2 & \\
\hline & \multirow{2}{*}{$\mathrm{P}$} & A3 & & B3 & & C3 & & D3 & & E3 & & F3 & & G3 & \\
\hline & & A4 & & B4 & & C4 & & D4 & & E4 & & F4 & & G4 & \\
\hline & \multirow{2}{*}{ N } & A5 & & B5 & & C5 & & D5 & & E5 & & F5 & & G5 & \\
\hline & & A6 & & B6 & & C6 & & D6 & & E6 & & F6 & & G6 & \\
\hline \multirow{6}{*}{$\begin{array}{l}\stackrel{\mathfrak{N}}{E} \\
\stackrel{\sim}{n} \\
\stackrel{n}{\sim} \\
\stackrel{\sim}{N}\end{array}$} & \multirow{2}{*}{ W } & A1 & & B1 & & C1 & & D1 & & E1 & & F1 & & & \\
\hline & & A2 & & B2 & & C2 & & D2 & & E2 & & F2 & & & \\
\hline & \multirow{2}{*}{$\mathrm{P}$} & A3 & & B3 & & C3 & & D3 & & E3 & & F3 & & & \\
\hline & & A4 & & B4 & & C4 & & D4 & & E4 & & F4 & & & \\
\hline & \multirow{2}{*}{$\mathrm{N}$} & A5 & & B5 & & $\mathrm{C} 5$ & & D5 & & E5 & & F5 & & & \\
\hline & & A6 & & B6 & & C6 & & D6 & & E6 & & F6 & & & \\
\hline Lege & & & & & $w-w$ & nik wy & & & P - wyni & prawic & owy & & J-wynik & iski & \\
\hline
\end{tabular}

Jeśli chodzi o sferę umiejętności komunikacyjnych i mowę, dziewczynka nie zawsze mówiła zrozumiale, nie potrafiła opowiedzieć treści obrazka przedstawiającego zabawy dzieci na dworze, ani powtórzyć dwuwersowej rymowanki. W obszarze wiedzy i umiejętności uczenia się: dziewczynka nie potrafiła odwzorować figur geometrycznych, umieścić klocka „za”, „przed”, „pod” i „obok” samochodziku, ale umiała położyć go zgodnie z poleceniem "na” samochodziku. M.L. nie umiała podzielić $\mathrm{z}$ pomocą wyklaskiwania wyrazów 2- i 3-sylabowych (np. mama, samolot) na sylaby.

Uzyskany profil rozwoju dziewczynki M.L. po 2 latach użytkowania CI prezentuje typowe opóźnienia rozwojowe, jakie występują u dzieci z głęboką głuchotą prelingwalną. $Z$ powodu opóźnionego procesu nabywania mowy i języka dziewczynka nie opanowała dostatecznie umiejętności budowania prostych zdań poprawnych gramatycznie, aby opisać rysunek. Mowa dziewczynki nie zawsze jest zrozumiała dla otoczenia, a powtórzenie dwuwersowej rymowanki było zadaniem zbyt trudnym do wykonania. Brak możliwości poprawnego wykonania prób z zakresu wiedzy i umiejętności uczenia się jest związany $\mathrm{z}$ zaburzonym rozwojem komunikacji i mowy, w tym $\mathrm{z}$ problemami $\mathrm{z}$ wysłuchiwaniem i wyklaskiwaniem rytmów oraz koordynacją słuchowo-ruchową i rozumieniem złożonych poleceń. Trudności z wykonaniem zadania, do którego niezbędna była znajomość przyimków, stanowią potwierdzenie wyników badań prowadzonych wśród dzieci z głuchotą prelingwalną z implantami ślimakowymi, zgodnie z którymi dzieci 3-6-letnie, będące użytkownikami CI, uzyskują gorsze wyniki w rozumieniu i stosowaniu przyimków niż ich słyszący rówieśnicy. Rozumienie przyimków „na”, „z”, „do” i „,w” sprawia dzieciom głuchym implantowanym najmniejsze trudności, co potwierdza wynik uzyskany przez M.L. [38].

Celem dalszej rehabilitacji powinno być usprawnianie komunikacji i mowy. Raz w roku należy przeprowadzać 
badania oceniające aktualny rozwój psychomotoryczny dziewczynki, wyniki których umożliwią zidentyfikowanie mocnych i słabych sfer jej funkcjonowania i ewentualne dopasowanie zajęć wspierających harmonijny rozwój. Dobrze byłoby włączyć też inne narzędzia do oceny umiejętności komunikowania się dziewczynki, np. Kartę Oceny Zachowań Komunikacyjnych autorstwa K. Krakowiak i M. Panasiuk [39], aby przyjrzeć się tej sferze rozwoju w wielu jej aspektach [40]. Wskazane jest też przyjrzenie się interakcjom matka (ojciec) - dziecko, by zobaczyć, jak one przebiegają, a także ocenić, czy rodzic/rodzice wymagają wsparcia psychologicznego [41]. Dostarczenie rodzicom prawidłowego wzorca interakcji z dzieckiem głuchym, drogą ich modelowania przez psychologa lub logopedę, może także sprzyjać rozwojowi mowy i języka u omawianej dziewczynki [15].

\section{Studium przypadku II}

Dziewczynka P.R. - w wieku 8 lat i 10 miesięcy, ze zdiagnozowanymi centralnymi zaburzeniami słuchu i opóźnionym rozwojem mowy, zdała do klasy trzeciej szkoły podstawowej; w rodzinie nie ma problemów ze słuchem. Badanie za pomocą KORP przeprowadzono w lipcu 2017 roku, kiedy dziecko rozpoczynało terapię SPS-artykulacja, połączoną z ćwiczeniami sensomotorycznymi.

Dane medyczne. Wywiad okołoporodowy obciążony, ciąża podtrzymywana $\mathrm{z}$ powodu zagrażającego przedwczesnego porodu. Matka otrzymywała leki przeciwskurczowe. Dziewczynka P.R. urodzona w 35 tygodniu ciąży przez cesarskie cięcie $z$ powodu dwóch poprzednich porodów matki przez cesarskie cięcie, $\mathrm{z}$ masą urodzeniową $3000 \mathrm{~g}$, otrzymała 10 punktów w skali Apgar. Dziecko zostało poddane fototerapii z powodu podwyższonego poziomu bilirubiny. W okresie noworodkowym stwierdzono u dziewczynki wzmożone napięcie mięśniowe i z tego powodu była rehabilitowana. W wieku 6 lat u dziewczynki przeprowadzono zabieg adenotomii.

Wyniki badań audiologicznych. Wynik badania przesiewowego słuchu dziewczynki na oddziale noworodkowym był prawidłowy. $\mathrm{W}$ momencie rozpoczęcia terapii progi słyszenia $\mathrm{w}$ audiometrii tonalnej były w normie, a w badaniu impedancyjnym zarejestrowano tympanogramy typu A, odruchy ipsilateralne i kontrlateralne z mięśnia strzemiączkowego były obecne obustronnie na poziomie 90-100 dB. W testach sprawdzających procesy przetwarzania informacji słuchowej na wyższych piętrach drogi słuchowej dziecko udzieliło w badaniach FPT - 17,5\%, DPT - 25\% poprawnych odpowiedzi przy wartościach normatywnych odpowiednio $42 \%$ i $40 \%$. W cyfrowym teście dychotycznym $z$ uwagą rozproszoną P.R. prawidłowo identyfikowała $\mathrm{z}$ ucha prawego $42,5 \%$ cyfr, a $\mathrm{z}$ lewego - 40\%, natomiast przy uwadze ukierunkowanej - odpowiednio $35 \%$ dla UP i $45 \%$ dla UL - wartości prawidłowe dla dzieci typowo się rozwijających w wieku dziewczynki wynoszą dla UP 75\%, a dla UL 65\% prawidłowo zidentyfikowanych cyfr.

Diagnoza sensomotoryczna i ocena pedagogiczna. U dziewczynki w rozwoju motorycznym nie występował etap raczkowania, a samodzielnie zaczęła chodzić w wieku 12 miesięcy. Aktualnie występuje u niej niezgrabność ruchowa, dziecko ma problemy z planowaniem ruchu Przeprowadzono także diagnozę sensomotoryczną, która wykazała niezintegrowane odruchy wczesnodziecięce: Moro, Palmara, Galanta, ATOS, STOS oraz w mniejszym nasileniu TOB i w związku z tym uczestniczyła $\mathrm{w}$ terapii SPS-artykulacja $\mathrm{z}$ dodatkowo prowadzonymi ćwiczeniami sensomotorycznymi.

$\mathrm{Z}$ wywiadu $\mathrm{z}$ matką oraz analizy wytworów dziecka wynika, że P.R. ma wolne tempo pracy, popełnia błędy w pisaniu i przepisywaniu (zamiana liter, opuszczanie), zaobserwowano także trudności w liczeniu w pamięci, dziewczynka nie potrafi mnożyć i dzielić. Obserwowane są zaburzenia koncentracji i wyłączenia uwagi, występują trudności w opanowaniu materiału na pamięć oraz szybka męczliwość. Matka zgłasza łatwe rozpraszanie się córki przez bodźce dźwiękowe z otoczenia; dziewczynka często prosi o powtórzenie pytań i informacji. Łatwiej jej zrozumieć zdania proste, natomiast kłopot sprawiają dziecku zdania złożone i wielokrotnie złożone. Zdaniem matki dziewczynka jest dzieckiem spokojnym i niezbyt zwinnym. Jazdę na rowerze bez bocznych kółek opanowała w wieku 7 lat.

Rozwój mowy i języka. Z powodu opóźnionego rozwoju mowy dziewczynka od 6. roku życia uczestniczy raz w tygodniu w zajęciach logopedycznych. Dziecko używało smoczka do około 3. roku życia. Pierwsze znaczące słowa pojawiły się w 12. miesiącu życia. Zdaniami zaczęła się posługiwać w wieku około 3 lat. Dziewczynka najchętniej posługuje się zdaniami prostymi i prostymi rozwiniętymi. Pojawiają się również zdania złożone, na ogół poprawne gramatycznie, lecz zniekształcone artykulacyjnie. P.R. prawidłowo posługuje się mową dialogową, jednak dużą trudność sprawia dziewczynce narracja (opowiadanie).

W badaniu wykonanym w Poradni Psychologiczno-Pedagogicznej zasób słownika dziecka oceniono jako przeciętny. Pomimo ćwiczeń dziewczynka nie utrwaliła prawidłowej realizacji głosek syczących i ciszących. Dziewczynka ma trudność z ich słuchowym odróżnieniem. Szeregi te są realizowane w sposób zdeformowany (międzyzębowość). Rehabilitację międzyzębowego ułożenia języka utrudnia nienormatywny schemat połykania i nieprawidłowa motoryka artykulacyjna - dziecko ma trudności z precyzją i wykonywaniem sekwencji ruchów niewyuczonych: warg, policzków, języka i podniebienia miękkiego.

Ocena aktualnego rozwoju psychoruchowego $\mathrm{z}$ wykorzystaniem KORP. Badanie za pomocą KORP przeprowadzono u dziewczynki przed rozpoczęciem terapii SPS-artykulacja z ćwiczeniami sensomotorycznymi. Wyniki uzyskane w poszczególnych testach umożliwiły wykreślenie profilu rozwoju psychoruchowego dziecka (rycina 3). W większości sfer funkcjonowania psychoruchowego P.R. wykazuje niski poziom rozwoju w porównaniu do dzieci rozwijających się typowo, będących w wieku biologicznym P.R. Jedynie umiejętności w sferze rozwoju emocjonalno-społecznego dziewczynka prezentowała na poziomie dzieci z grupy normatywnej.

Rozwój ruchowy P.R., motoryki precyzyjnej i lateralizacji oraz funkcji behawioralnych odpowiadał przeciętnemu poziomowi dzieci 7-letnich, a umiejętności 
Rycina 3. Karta KORP dziewczynki P.R.

Figure 3. KORP profile for the subject P.R.

\begin{tabular}{|c|c|c|c|c|c|c|c|c|c|c|c|c|c|c|c|}
\hline \multicolumn{16}{|c|}{ Karty Oceny Rozwoju Psychoruchowego } \\
\hline \multirow[t]{2}{*}{$\begin{array}{l}\frac{3}{v} \\
\frac{0}{3} \\
\frac{0}{3} \\
. \frac{0}{N} \\
0 \\
\therefore\end{array}$} & \multirow[t]{2}{*}{$\begin{array}{l}\varepsilon \\
\frac{\varepsilon}{N} \\
\stackrel{\circ}{0}\end{array}$} & \multicolumn{2}{|c|}{$\begin{array}{l}\text { Rozwój } \\
\text { ruchowy }\end{array}$} & \multicolumn{2}{|c|}{$\begin{array}{c}\text { Rozwój } \\
\text { motoryki } \\
\text { precyzyjnej } \\
\text { i lateralizacji }\end{array}$} & \multicolumn{2}{|c|}{$\begin{array}{c}\text { Rozwój } \\
\text { spostrzegania } \\
\text { wzrokowego } \\
\text { i koordynacji } \\
\text { wzrokowo- } \\
\text { ruchowej }\end{array}$} & \multicolumn{2}{|c|}{$\begin{array}{c}\text { Rozwój } \\
\text { komunikowania } \\
\text { się i mowy }\end{array}$} & \multicolumn{2}{|c|}{$\begin{array}{l}\text { Rozwój } \\
\text { emocjonalno- } \\
\text { społeczny }\end{array}$} & \multicolumn{2}{|c|}{$\begin{array}{l}\text { Rozwój funkcji } \\
\text { behavioralnych }\end{array}$} & \multicolumn{2}{|c|}{$\begin{array}{c}\text { Wiedza } \\
\text { i umiejętności } \\
\text { uczenia się }\end{array}$} \\
\hline & & Próby & Poziom & Próby & Poziom & Próby & Poziom & Próby & Poziom & Próby & Poziom & Próby & Poziom & Próby & Poziom \\
\hline \multirow{6}{*}{ 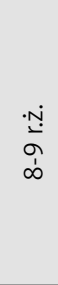 } & \multirow{2}{*}{ W } & A1 & & B1 & & $\mathrm{C} 1$ & & D1 & & E1 & & F1 & & G1 & \\
\hline & & $\mathrm{A} 2$ & & B2 & & $\mathrm{C} 2$ & & D2 & & E2 & & $\mathrm{F} 2$ & & G2 & \\
\hline & \multirow{2}{*}{$P$} & A3 & & B3 & & $\mathrm{C} 3$ & & D3 & & E3 & & F3 & & G3 & \\
\hline & & A4 & & B4 & & C4 & & D4 & & E4 & & $\mathrm{F} 4$ & & G4 & \\
\hline & \multirow{2}{*}{ N } & A5 & & B5 & & C5 & & D5 & & E5 & & F5 & & G5 & \\
\hline & & A6 & & B6 & & $\mathrm{C} 6$ & & D6 & & E6 & & F6 & & G6 & \\
\hline \multirow{6}{*}{$\stackrel{n}{\stackrel{n}{n}}$} & \multirow{2}{*}{ W } & A1 & & B1 & & $\mathrm{C} 1$ & & D1 & & E1 & & $\mathrm{F} 1$ & & G1 & \\
\hline & & $A 2$ & & B2 & & $\mathrm{C} 2$ & & D2 & & E2 & & F2 & & $\mathrm{G} 2$ & \\
\hline & \multirow{2}{*}{$P$} & A3 & & B3 & & $\mathrm{C} 3$ & & D3 & & E3 & & F3 & & G3 & \\
\hline & & A4 & & B4 & & $\mathrm{C} 4$ & & D4 & & E4 & & $\mathrm{F} 4$ & & G4 & \\
\hline & \multirow{2}{*}{$\mathrm{N}$} & A5 & & B5 & & $\mathrm{C} 5$ & & D5 & & E5 & & F5 & & G5 & \\
\hline & & A6 & & B6 & & $\mathrm{C} 6$ & & D6 & & E6 & & F6 & & G6 & \\
\hline \multirow{6}{*}{ ํㅗํ } & \multirow{2}{*}{ W } & A1 & & B1 & & $\mathrm{C} 1$ & & D1 & & E1 & & $\mathrm{F} 1$ & & G1 & \\
\hline & & A2 & & B2 & & $\mathrm{C} 2$ & & D2 & & E2 & & F2 & & G2 & \\
\hline & \multirow{2}{*}{$P$} & A3 & & B3 & & $\mathrm{C} 3$ & & D3 & & E3 & & F3 & & G3 & \\
\hline & & A4 & & B4 & & C4 & & D4 & & E4 & & F4 & & G4 & \\
\hline & \multirow{2}{*}{ N } & A5 & & B5 & & $\mathrm{C} 5$ & & D5 & & E5 & & F5 & & G5 & \\
\hline & & $A 6$ & & B6 & & C6 & & D6 & & E6 & & F6 & & G6 & \\
\hline Lege & & & & & $w-n$ & nik wy & & & P - wynik & prawi & owy & & - wynik & iski & \\
\hline
\end{tabular}

komunikacyjnych i mowy oraz prezentowanej wiedzy - dzieci 6-letnich. W ramach prób sprawdzających poziom rozwoju ruchowego dziewczynka nie potrafiła, skacząc na jednej nodze, wykonać slalomu między przedmiotami umieszczonymi na podłodze, ani powtórzyć sekwencji ruchowej wymagającej m.in. podrzucenia i złapania piłki po klaśnięciu. Z obszaru motoryki precyzyjnej i lateralizacji - nie potrafiła dokładnie wydrzeć kształtów figur geometrycznych narysowanych na kartce papieru, nie przerywając ich konturów, tasować kart ani wykonać starannie i estetycznie pracy plastycznej bogatej w szczegóły. Dziewczynka nadal ma nie w pełni ustaloną lateralizację dominującej ręki w zadaniach grafomotorycznych.

Wykreślony profil rozwoju psychoruchowego P.R. wskazuje na niski poziom funkcjonowania $w$ granicach norm dla wieku w 6 sferach. Funkcjonowanie społeczno-emocjonalne dziewczynki w odniesieniu do grupy normatywnej jest właściwe dla jej wieku biologicznego i osiąga poziom prawidłowy. Jednakże należy mieć na uwadze, że dzieci z zaburzeniami przetwarzania słuchowego znajdują się w grupie ryzyka występowania problemów w sferze zdrowia psychicznego [17], co sugeruje zaproponowanie jej wsparcia psychologicznego, między innymi w formie treningu umiejętności społecznych [18].

\section{Studium przypadku III}

Chłopiec P.A. - w wieku 4 lat i 1 miesiąca, z jednostronną głuchotą ucha prawego, użytkownik CI, badany po 24 miesiącach od aktywacji CI; w rodzinie problemy ze słuchem nie występują; P.A. chodzi do przedszkola, młodszy brat słyszy.

Dane medyczne. Urodzony w 36 tygodniu ciąży siłami natury, z masą urodzeniową 2920 g, otrzymał 7 punktów w skali Apgar. W trakcie ciąży matka przeszła zapalenie dróg moczowych, a chłopiec po urodzeniu dostawał gentamycynę. Stany zapalne uszu z wyciekami nie występowały. Rozwój motoryczny przebiegał prawidłowo. Wad wrodzonych i chorób przewlekłych nie stwierdzono. Chłopiec przeszedł zabieg podcięcia wędzidełek. Wynik badania USG przezciemiączkowego $\mathrm{w}$ normie. $\mathrm{W}$ badaniach molekularnych nie wykryto najczęstszych mutacji genu: GJB2 i GJB6, ani mutacji mitochondrialnego DNA m.1555A $>$ G.

Wyniki badań audiologicznych. Wynik przesiewowego badania słuchu był nieprawidłowy dla ucha prawego i został potwierdzony dwukrotnie w badaniu ABR, podczas którego nie zarejestrowano odpowiedzi dla bodźca $1000 \mathrm{~Hz}$ i dla sygnału trzask do intensywności do $100 \mathrm{~dB}$; progi odpowiedzi dla ucha lewego były w normie (10 i $20 \mathrm{~dB}$ nHL). 
Rycina 4. Karta KORP chłopca P.A.

Figure 4. KORP profile for the subject P.A.

\begin{tabular}{|c|c|c|c|c|c|c|c|c|c|c|c|c|c|c|c|}
\hline \multicolumn{16}{|c|}{ Karty Oceny Rozwoju Psychoruchowego } \\
\hline \multirow[t]{2}{*}{$\begin{array}{l}\frac{2}{2} \\
\frac{0}{3} \\
\frac{E}{2} \\
\frac{0}{N} \\
O \\
\varrho\end{array}$} & \multirow[t]{2}{*}{$\begin{array}{l}\frac{E}{0} \\
.0 \\
0 \\
0\end{array}$} & \multicolumn{2}{|c|}{$\begin{array}{l}\text { Rozwój } \\
\text { ruchowy }\end{array}$} & \multicolumn{2}{|c|}{$\begin{array}{c}\text { Rozwój } \\
\text { motoryki } \\
\text { precyzyjnej } \\
\text { i lateralizacji }\end{array}$} & \multicolumn{2}{|c|}{$\begin{array}{c}\text { Rozwój } \\
\text { spostrzegania } \\
\text { wzrokowego } \\
\text { i koordynacji } \\
\text { wzrokowo- } \\
\text { ruchowej }\end{array}$} & \multicolumn{2}{|c|}{$\begin{array}{c}\text { Rozwój } \\
\text { komunikowania } \\
\text { się i mowy }\end{array}$} & \multicolumn{2}{|c|}{$\begin{array}{c}\text { Rozwój } \\
\text { emocjonalno- } \\
\text { społeczny }\end{array}$} & \multicolumn{2}{|c|}{$\begin{array}{l}\text { Rozwój funkcji } \\
\text { behavioralnych }\end{array}$} & \multicolumn{2}{|c|}{$\begin{array}{c}\text { Wiedza } \\
\text { i umiejętności } \\
\text { uczenia się }\end{array}$} \\
\hline & & Próby & Poziom & Próby & Poziom & Próby & Poziom & Prób) & Poziom & Prób & Poziom & Próby & Poziom & Próby & Poziom \\
\hline \multirow{6}{*}{$\stackrel{\text { 뜬 }}{\stackrel{n}{n}}$} & \multirow{2}{*}{ W } & $\mathrm{A} 1$ & & B1 & & $\mathrm{C} 1$ & & D1 & & E1 & & $\mathrm{F} 1$ & & G1 & \\
\hline & & $\mathrm{A} 2$ & & B2 & & $\mathrm{C} 2$ & & D2 & & E2 & & F2 & & $\mathrm{G} 2$ & \\
\hline & \multirow{2}{*}{$P$} & A3 & & B3 & & C3 & & D3 & & E3 & & $\mathrm{F} 3$ & & G3 & \\
\hline & & A4 & & B4 & & $\mathrm{C} 4$ & & D4 & & E4 & & $\mathrm{F} 4$ & & $\mathrm{G} 4$ & \\
\hline & \multirow{2}{*}{$\mathrm{N}$} & A5 & & B5 & & $\mathrm{C} 5$ & & D5 & & E5 & & F5 & & G5 & \\
\hline & & A6 & & B6 & & C6 & & D6 & & E6 & & F6 & & G6 & \\
\hline \multirow{6}{*}{ 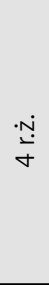 } & \multirow{2}{*}{ W } & A1 & & B1 & & $\mathrm{C} 1$ & & D1 & & E1 & & $\mathrm{F} 1$ & & G1 & \\
\hline & & $\mathrm{A} 2$ & & B2 & & $\mathrm{C} 2$ & & D2 & & E2 & & F2 & & $\mathrm{G} 2$ & \\
\hline & \multirow{2}{*}{$P$} & A3 & & B3 & & $\mathrm{C} 3$ & & D3 & & E3 & & F3 & & G3 & \\
\hline & & A4 & & B4 & & C4 & & D4 & & E4 & & $\mathrm{F} 4$ & & G4 & \\
\hline & \multirow{2}{*}{$\mathrm{N}$} & A5 & & B5 & & $\mathrm{C} 5$ & & D5 & & E5 & & F5 & & G5 & \\
\hline & & A6 & & B6 & & C6 & & D6 & & E6 & & F6 & & G6 & \\
\hline \multirow{6}{*}{$\stackrel{\text { Nㅗㅁ }}{m}$} & \multirow{2}{*}{ W } & $\mathrm{A} 1$ & & B1 & & $\mathrm{C} 1$ & & D1 & & $\mathrm{E} 1$ & & $\mathrm{~F} 1$ & & G1 & \\
\hline & & $\mathrm{A} 2$ & & B2 & & $\mathrm{C} 2$ & & D2 & & E2 & & F2 & & $\mathrm{G} 2$ & \\
\hline & \multirow{2}{*}{$P$} & A3 & & B3 & & $\mathrm{C} 3$ & & D3 & & E3 & & F3 & & G3 & \\
\hline & & A4 & & B4 & & C4 & & D4 & & E4 & & $\mathrm{F} 4$ & & G4 & \\
\hline & \multirow{2}{*}{$\mathrm{N}$} & A5 & & B5 & & $\mathrm{C} 5$ & & D5 & & E5 & & F5 & & G5 & \\
\hline & & A6 & & B6 & & C6 & & D6 & & E6 & & F6 & & G6 & \\
\hline \multirow{6}{*}{ 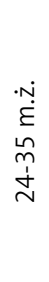 } & \multirow{2}{*}{ W } & $\mathrm{A} 1$ & & B1 & & $\mathrm{C} 1$ & & D1 & & E1 & & $\mathrm{F} 1$ & & & \\
\hline & & A2 & & B2 & & $\mathrm{C} 2$ & & D2 & & E2 & & $\mathrm{F} 2$ & & & \\
\hline & \multirow{2}{*}{$P$} & A3 & & B3 & & $\mathrm{C} 3$ & & D3 & & E3 & & F3 & & & \\
\hline & & A4 & & B4 & & C4 & & D4 & & E4 & & $\mathrm{F} 4$ & & & \\
\hline & \multirow{2}{*}{$\mathrm{N}$} & A5 & & B5 & & C5 & & D5 & & E5 & & F5 & & & \\
\hline & & A6 & & B6 & & C6 & & D6 & & E6 & & F6 & & & \\
\hline Lege & & & & & $W-v$ & $i k$ w & & & P - wynik & rawi & wy & & - wynik & iski & \\
\hline
\end{tabular}

Aparat słuchowy na UP nosił chętnie od 6. miesiąca życia przez 10 miesięcy, a po przerwie - spowodowanej awarią aparatu słuchowego - nie chciał go już nosić.

Rozwój mowy i języka. Mowa rozwija się prawidłowo. Rodzice obserwowali trudności komunikacyjne u syna w utrudnionych warunkach akustycznych, np. na placu zabaw czy w głośnym otoczeniu. P.A. miał wtedy problemy $\mathrm{z}$ selekcją istotnych $\mathrm{w}$ danym momencie bodźców dźwiękowych.

Ocena aktualnego rozwoju psychoruchowego $\mathrm{z}$ wykorzystaniem KORP. Badanie za pomoca KORP wykonano po 2 latach korzystania $\mathrm{z}$ CI w uchu prawym. Wykreślony profil rozwoju psychoruchowego (rycina 4) wskazuje na prawidłowe funkcjonowanie chłopca we wszystkich badanych obszarach. W zakresie rozwoju funkcjonowania emocjonalno-społecznego oraz wiedzy i umiejętności uczenia się chłopiec wykazał wysoki poziom w odniesieniu do wieku biologicznego, a w sferze spostrzegania wzrokowego i koordynacji wzrokowo-ruchowej - zaprezentował umiejętności na poziomie dzieci 5-letnich rozwijających się typowo.

Uzyskane przez chłopca wyniki w KORP świadczą o harmonijnym rozwoju pomimo stwierdzonego jednostronnego głębokiego niedosłuchu zmysłowo-nerwowego. Zastosowanie CI umożliwiło dziecku słyszenie binauralne, które ułatwia m.in. lokalizację źródła dźwięku w płaszczyźnie horyzontalnej, oraz poprawiło rozumienie mowy w utrudnionych warunkach akustycznych [42]. Takie rezultaty wykazały wyniki badań prowadzonych w IFPS [43-45] oraz przez badaczy zagranicznych. Na znaczącą poprawę rozumienia mowy w ciszy i w hałasie u pacjentów z CI wskazują wyniki badań przeprowadzonych w USA na grupie 5 dzieci i 20 dorosłych z SSD [46-47]. 


\section{Wnioski}

- KORP może być używany jako narzędzie umożliwiające przeprowadzenie wstępnej diagnozy rozwoju psychoruchowego dzieci z zaburzeniami słuchu i mowy.

- Uzyskane w tym badaniu wyniki mogą ułatwiać planowanie wielospecjalistycznej pomocy dzieciom $\mathrm{z}$ zaburzonym rozwojem psychoruchowym, tj. wskazywać, w jakich obszarach funkcjonowania dziecka należy przeprowadzić specjalistyczną pogłębioną diagnozę, a po potwierdzeniu nieprawidłowości rozwojowych - jakie leczenie, rehabilitacja i terapia zaburzonych sfer rozwoju będą odpowiednie.

- Badanie za pomocą KORP można także wykorzystać w celu ewaluacji zastosowanych form wsparcia specjalistyczno-rehabilitacyjnego.

\section{Piśmiennictwo}

1. Bogdanowicz M. Problematyka zaburzeń rozwoju psychoruchowego dziecka. W: Logopedia pytania i odpowiedzi. Gałkowski T, Jastrzębowska G (red.). Opole: Wydawnictwo Uniwersytetu Opolskiego; 2003, s. 225-29.

2. Odowska-Szlachcic B, Mierzejewska B. Wzrok i słuch - zmysły wiodące w uczeniu się w aspekcie integracji sensorycznej. Gdańsk: Harmonia Universalis; 2013.

3. Kurkowski Z. Centralne zaburzenia przetwarzania słuchowego. W: Surdologopedia. Teoria i praktyka. Furtak E (red.). Gdańsk: Harmonia Universalis; 2015, s. 54-57.

4. Pankowska A, Geremek-Samsonowicz A, Skarżyński H. Implanty ślimakowe w częściowej głuchocie. Zadania i formy rehabilitacji dzieci. W: Surdologopedia. Teoria i praktyka. Furtak E (red.). Gdańsk: Harmonia Universalis; 2015, s. 329-42.

5. Pankowska A, Barej A, Lutek A, Zgoda M, Zielińska E. Metoda Audytywno-Werbalna w rehabilitacji słuchu i mowy dzieci z wadą słuchu - historia, zasady i praktyka. Now Audiofonol, 2013; 2(4): 22-27.

6. Rostkowska J, Pankowska A. Cele rehabilitacji słuchowej przeznaczonej dla dzieci i dorosłych korzystających z implantu ślimakowego. Now Audiofonol, 2016; 5(1): 58-63.

7. Milner R, Ganc M, Czajka N, Trzaskowski B, Piotrowska A, Kurkowski Z, Kochanek K, Skarżyński H. Zastosowanie terapii neurofeedback w poprawie wyższych funkcji słuchowych u dzieci z ośrodkowymi zaburzeniami słuchu - wyniki wstępne. Now Audiofonol, 2012; 1(1): 67-78.

8. Ganc M, Milner R, Jędrzejczak W, Skarżyński H. Terapia EEG Biofeedback 9-letniego ucznia szkoły podstawowej z zespołem nadpobudliwości psychoruchowej i ośrodkowymi zaburzeniami przetwarzania słuchowego - studium przypadku. Studia Pedagogiczne. Problemy społeczne, edukacyjne i artystyczne, 2017; 29: 167-87.

9. Ratyńska J. Zastosowanie metody Tomatisa. W: Metoda Tomatisa. Publikacja końcowa projektu „Uwaga! Sposób na sukces”. Gdańsk: Young Digital Planet; 2013, s. 55-59.

10. Czajka N, Grudzień D, Pluta A, Kurkowski Z, Ganc M, Cieśla K, Skarżyński H. Efekty terapii Stymulacji Percepcji Słuchowej (SPS-S) u dzieci z zaburzeniami koncentracji uwagi słuchowej oraz centralnymi zaburzeniami przetwarzania słuchowego. Now Audiofonol, 2012; 1(1): 79-86.

11. Walencik-Topiłko A, Wysocka M. Logorytmika w terapii surdologopedycznej. W: Surdologopedia. Teoria i praktyka. Furtak E (red.). Gdańsk: Harmonia Universalis; 2015, s. 343-353.

12. Szuchnik J. Metoda psychomotoryczna Procus i Block w pracy z grupa dzieci implantowanych. Audiofonologia, 2005; 27: 91-95.

13. Kułakowska Z, Borkowska M, Zychowicz B. Terapia psychomotoryczna dzieci metodą Procus i Block. Warszawa: Wydawnictwo Lekarskie PZWL; 2012.

14. Chudoba U, Krawiec M. Z doświadczeń wspomagania terapii logopedycznej dzieci z wadą słuchu metodą W. Sherborne. W: Bliżej życia. Materiały dla rodziców dzieci i młodzieży z wadą słuchu. Kobosko J (red.). Warszawa: Stowarzyszenie Przyjaciół Osób Niesłyszących i Niedosłyszących „Człowiek-Człowiekowi”; 2001, s. 280-85.
15. Kobosko J. Wspieranie rozwoju kompetencji społecznych u dzieci głuchych i słabo słyszących. W: Umiejętności społeczne dzieci. Kształtowanie rozwoju emocjonalno-społecznego dzieci w normie rozwojowej i dzieci ze specjalnymi potrzebami edukacyjnymi. Jegier A, Szurowska B (red.). Warszawa: Difin; 2017, s. $81-103$.

16. Kobosko J. Pomoc psychologiczna słyszącym rodzicom a efektywność rehabilitacji dziecka głuchego. Otorynolaryngologia - przegląd kliniczny, 2011; 10(1): 8-14.

17. Rostkowska J, Kobosko J, Kłonica K. Problemy emocjonalno-społeczne i behawioralne u dzieci z centralnymi zaburzeniami przetwarzania słuchowego (CAPD) w ocenie rodziców. Now Audiofonol, 2013; 2(1): 29-35.

18. Rostkowska J, Wojewódzka B. Dzieci z zaburzeniem przetwarzania słuchowego (APD). W: Umiejętności społeczne dzieci. Kształtowanie rozwoju emocjonalno-społecznego dzieci w normie rozwojowej i dzieci ze specjalnymi potrzebami edukacyjnymi. Jegier A, Szurowska B (red.). Warszawa: Difin, 2017, s. 104-13.

19. Stachyra J. Zdolności poznawcze i możliwości umysłowe uczniów z uszkodzonym słuchem. Lublin: Wydawnictwo UMCS; 2001.

20. Kobosko J. Problemy zdrowia psychicznego dzieci głuchych i słabosłyszących oraz dzieci słyszących z populacji ogólnej w ocenie rodziców. Now Audiofonol, 2012; 1(1): 56-66.

21. Kosowska M. Specyfika rozwoju psychospołecznego dziecka z wadą słuchu. W: Relacje dziecka z wadą słuchu w szkole. Jegier A, Kosowska M (red.). Warszawa: Difin; 2011, s. 53-60.

22. Mandal JC, Kumar S, Roy S. Comparison of auditory comprehension skill in children with cochlear implant and typically developing children. Int J Pediatr Otorhinolaryngol, 2016; 91: 113-20.

23. Umat C, Zamratol-Mai S, Mukari S, Nordin N, Annamalay T, Othman BF. Mainstream school readiness skill of a group of young cochlear implant users. Int J Pediatr Otorhinolaryngol, 2018; 107: 69-74.

24. Zgoda M, Lorens A, Obrycka A, Putkiewicz-Aleksandrowicz J, Skarżyński H. Osiągnięcia szkolne na zakończenie nauki w szkole podstawowej użytkowników implantów ślimakowych a wiek, w którym przeprowadzono operację. Now Audiofonol, 2017; 6(1): 43-51.

25. Lieu J. Permanent Unilateral Hearing Loss (UHL) and childhood development. Curr Otorhinolaryngol Rep, 2018; 6: 74-81.

26. Mertens G, De Bodt M, Van de Heyning P. Evaluation of long-term cochlear implant use in subjects with acquired unilateral profound hearing loss. Focus on binaural auditory outcomes. Ear Hear, 2017; 38(1): 117-25.

27. Skoczylas A, Lewandowska M, Pluta A, Kurkowski Z, Skarżyński H. Ośrodkowe zaburzenia słuchu - wskazówki diagnostyczne i propozycje terapii. Now Audiofonol, 2012; 1(1): 11-18.

28. Zaborniak-Sobczak M, Bieńkowska KI, Drozd M, Senderski A. Wsparcie edukacyjne uczniów $\mathrm{z}$ centralnymi zaburzeniami przetwarzania słuchowego. Niepełnosprawność. Dyskursy pedagogiki specjalnej, 2018; 28: 115-31. 
29. Kurkowski ZM. Audiogenne uwarunkowania zaburzeń komunikacji językowej. Lublin: Wydawnictwo UMCS; 2013.

30. Samsonowicz K, Skoczylas A, Fludra M, Geremek-Samsonowicz A. Trudności językowe i szkolne u 8-letniego chłopca z zaburzeniami przetwarzania słuchowego. Now Audiofonol, 2014; 3(4): 47-54.

31. Szkielkowska A, Senderski A, Ratyńska J, Markowska J, Kurkowski ZM, Mularzuk M. Zaburzenia procesów przetwarzania słuchowego u dzieci z dysleksją rozwojową. Audiofonologia, 2004; 26: 63-65.

32. Frydrychowicz A. Testy psychologiczne i pedagogiczne w poradnictwie. Warszawa: CMPPP; 1998.

33. Krasowicz-Kupis G, Wiejak K, Gruszczyńska K. Katalog metod diagnozy rozwoju poznawczego dziecka na etapie edukacji przedszkolnej i wczesnoszkolnej. Tom I - Narzędzia dostępne w poradniach psychologiczno-pedagogicznych i szkołach. Warszawa: Instytut Badań Edukacyjnych; 2014.

34. Matczak A, Jaworowska A, Ciechanowicz A, Fecenec D, Stańczak J, Zalewska E. DSR. Dziecięca Skala Rozwojowa. Warszawa: Pracownia Testów Psychologicznych; 2007.

35. Jaworowska A, Matczak A, Szustrowa T. Międzynarodowa Wykonaniowa Skala Leitera. Warszawa: Pracownia Testów Psychologicznych; 1996.

36. Pracownia Testów Psychologicznych Polskiego Towarzystwa Psychologicznego; https://www.practest.com.pl/ [dostęp: 30.07.2019].

37. Bogacz E, Bogacz-Rybczak A, Gruba J. KORP. Karty Oceny rozwoju Psychoruchowego - podręcznik. Gliwice: Komlogo; 2018.

38. Solnica J. Nabywanie umiejętności prawidłowego rozumienia i użycia przyimków przez dzieci słyszące i ich implantowanych rówieśników - doniesienia z badań własnych. Now Audiofonol, 2012; 1(1): 50-55.

39. Krakowiak K, Panasiuk M. Umiejętności komunikacyjne dziecka z uszkodzonym słuchem. Komunikacja językowa i jej zaburzenia, t. 3. Lublin: Wydawnictwo UMCS; 1992.
40. Antczak-Kujawin J. Ocena rozwoju sprawności komunikacyjnych dziecka z prelingwalnym głębokim uszkodzeniem narządu słuchu - studium przypadku. Otorynolaryngologia - przegląd kliniczny, 2017; 16(3): 119-24.

41. Kobosko J. Wsparcie emocjonalne dla rodziców dzieci głuchych i słabo słyszących w ramach terapii surdologopedycznej. Now Audiofonol, 2016; 5(1): 64-73.

42. Pastuszak D, Kruszyńska M, Lorens A, Skarżyński PH, Skarżyński H. Trening słuchowy u dorosłych pacjentów z jednostronnym głębokim niedosłuchem, użytkowników implantów ślimakowych. Now Audiofonol, 2018; 7(4): 41-46.

43. Skarżyński H, Lorens A, Kruszyńska M, Obrycka A, Pastuszak D, Skarżyński PH. The hearing benefit of cochlear implantation for individuals with unilateral hearing loss, but no tinnitus. Acta Otolaryngol, 2017; 137(7): 723-29.

44. Kruszyńska M, Lorens A, Obrycka A, Pastuszak D, Skarżyński H. Efekty binauralne u pacjentów z jednostronną głuchotą i pacjentów z asymetrycznym niedosłuchem, użytkowników systemu implantu ślimakowego. Now Audiofonol, 2016; 5(4): 43-48.

45. Lorens A, Kruszyńska M, Obrycka A, Skarżyński PH, Wilsondand B, Skarżyński H. Binaural advantages in using a cochlear implant for adults with profound unilateral hearing loss. Acta Otolaryngol, 2019; 139(2): 153-61.

46. Friedmann DR, Ahmed OH, McMenomey SO, Shapiro WH, Waltzman SB, Roland JT Jr. Single-sided deafness cochlear implantation: candidacy, evaluation, and outcomes in children and adults. Otol Neurotol, 2016; 37(2): e154-60.

47. Firszt JB, Reeder RM, Holden LK. Unilateral Hearing Loss: Understanding Speech Recognition and Localization Variability - Implications for Cochlear Implant Candidac. Ear Hear, 2017; 38(2): 159-73. 